\title{
Can Chinese Individuals Request the Restitution of Chinese Cultural Relics in Japan?: A Revisit under International Law
}

\author{
Hui Zhong*
}

During the Japanese Occupation of China (1931-45), countless Chinese cultural relics were simply destroyed or looted in accordance with Japan's notorious 'Three Alls Campaign,' also known as 'Burn all, loot all, and kill all'. Due to the 1972 Japan-Chian Joint Communiqué, however, the Chinese Government renounced its demand for war reparation from Japan. The question then becomes whether, when the Chinese Government renounced its claims for war reparations in a peace treaty. Chinese individuals still have a means to vindicate their rights to request restitution of Chinese cultural relics from Japan. The primary purpose of this research is to tackle two questions: First, was the taking of Chinese cultural relics during the Japanese Occupation prohibited by law? Second, can the Chinese individuals legally require the restitution of looted cultural relics? This paper handles a case of a 1300-year's old Tang dynasty stele in Japan which has been asked to hand over to China since 2014.

\section{Keywords}

Chinese Cultural Relics, Japanese Occupation, Restitution and Individual Requests

\footnotetext{
Research Fellow at TC Beirne School of Law at the University of Queensland. LL.B. (Guangdong Univ. of Foreign Studies), Ph.D. (Queensland). ORCID: http://orcid.org/0000-0003-4103-6328. This paper is fully revised and updated version of the author's doctoral dissertation presented to the graduate committee of the University of Queensland, Australia. The author may be contacted at: hui.zhong@uq.net.au / Address: TC Beirne School of Law, Forgan Smith Building, St Lucia Campus, Queensland, Australia. DOI: http://dx.doi.org/10.14330/jeail.2017.10.1.09
} 


\section{Introduction}

In August 2014, the China Federation of Demanding Compensation from Japan called on Japan to hand over a 1300-year's old Tang dynasty stele from the northeastern city of Lushun. ${ }^{1}$ This Tang dynasty stele carries considerable historical meaning and significance for defining a border for the Tang dynasty (618-906) and includes an inscription of 29 Chinese characters mentioning Tang emissary, Cui Xin, who gave instructions for two wells to be dug. However, it was found in the early twentieth century and shipped by the Japanese military to Tokyo, as a trophy of Japan's victory over the Russians in 1905. Afterward, the Tang-era stele was placed in the Imperial Palace in Tokyo.

Figure 1: Tang Dynasty Stele in Tokyo ${ }^{2}$

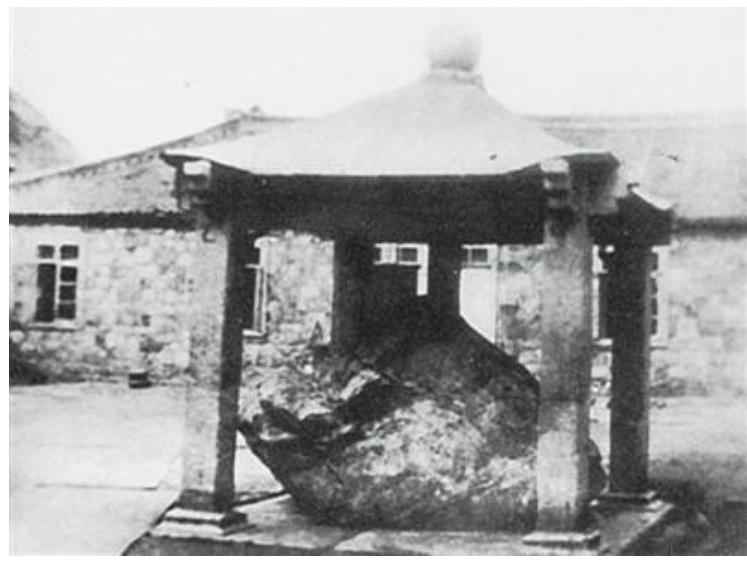

Chinese scholars have suggested that the stele should be displayed in a place where the public can enjoy it, since it is not just Chinese people who cannot see the stele but Japanese, as well. ${ }^{3}$ However, Japan declined to move it maintaining that: "The Tang

1 J. Perlez \& B. Feng, Chinese Group Calls on Japan to Hand Over Tang-Era Stele, N.Y. Times, Aug. 21, 2014, available at $\mathrm{http} / /$ sinosphere.blogs.nytimes.com/2014/08/21/chinese-group-calls-on-japan-to-hand-over-tang-era-stele (last visited on Apr. 15, 2017).

2 Q. Chen \& Y.Yang, Chinese Group Requested the Return of Chinese Cultural Relics from Japan, 中国民间首向日皇 室追讨文物, BEIJING TIMES, Aug. 11, 2014, available at http://epaper.jinghua.cn/html/2014-08/11/content_113474.htm (last visited on Apr. 18, 2017).

3 Perlez \& Feng, supra note 1. See also Chinese Academics Request the Return of Tang Dynasty Stele from 
stele is Japan's national property and should be displayed within the Palace. Nobody was allowed to enter the Place unless permitted. Only pictures can be provided."4 A Chinese civil group has finally asked Japan for the return of that cultural item. While the Foundation has not received a reply from Japanese authorities yet, it is worth looking at the legal grounds for Chinese individuals or groups to request the restitution of the Tang-stele in a court.

The primary purpose of this research is to tackle two questions: First, was the captivation of Chinese cultural relics during the Japanese Occupation prohibited by law? Second, can the Chinese individuals legally require the restitution of looted cultural relics? ${ }^{5}$ This paper is composed of five parts including a short Introduction and Conclusion. Part two will provide how Chinese cultural relics were looted during Japanese Occupation. Part three will examine the legal regime for prohibiting the looting of cultural property during armed conflicts and analyse the consequence of the 1972 Joint Communiqué. ${ }^{6}$ Part four will examine the legal issues arising from individuals' claims for unlawful acts by states during armed conflicts, which have been invoked by Japan in numerous cases in order to evade responsibility.

\section{A Historical Perspective: Looting of Chinese Cultural Relics}

During the Japanese Occupation (1931-45) ${ }^{8}$, a large-scale of Chinese cultural relics were destroyed and looted. E.g., Chongqing 重庆, with a long history dating back at least 3,000 years, enjoyed a prestigious historical reputation and was famous for a series of Chinese religious sculptures and carvings, depicted and influenced by Buddhist, Confucian and Taoist beliefs. However, the dreadful carpet bombing of

Japan 中国学术界要求日本归还唐代石碑遭拒绝, TENCENT NEWS, June 2, 2006, available at http://news.qq.com/a/ 20060602/002248.htm (last visited on Apr. 15, 2017).

4 Id.

5 The responses to reparations claims involving historical injustices usually include apology, restitution, compensation, rejection and law. This paper does not aim to distinguish any specific response. For details, see D. Shelton, The World of Atonement: Reparations for Historical Injustices, 50 NETH. INT'L L. Rev. 297-305 (2003).

6 Joint Communiqué of the Government of Japan and the Government of the People's Republic of China of 1972 (hereinafter 1972 Joint Communiqué), Ministry of Foreign Affairs of Japan, available at http://www.mofa.go.jp/ region/asia-paci/china/joint72.html (last visited on Apr. 15, 2017).

7 This section contains short excerpts, or similar language. See Hui Zhong, Legal Protection of Chinese Cultural Relics: A Justification for the Return, 20 ART, ANTIQUTT \& L. 47 (2015).

8 Japan started fighting against China intermittently since 1931, but the total war started in 1937. 
Chongqing during the period of 1938 to 1944 was reportedly destroyed 741 historical sites, more than 15,000 paintings and over 3,000,000 books. ${ }^{9}$ Enormous numbers of relics were looted, not to speak.

China has so far criticized and traded its interests to these "looted cultural heritages." In the auction case of two Chinese sculptures looted from the Summer Palace during the Second Opium War, the Chinese Government resolutely urged Christie's to stop the sale, stating that: "China does not acknowledge what it called the illegal possession of the two sculptures and would continue to seek the return of the sculptures by all means in accordance with relevant international conventions and Chinese laws." 10

In the recovery of Chinese cultural relics, however, the first hurdle China should pass is the question of 'legitimacy' while looting an enemy's property was regarded as war booty in ancient time. China should demonstrate since when such looting has been formally forbidden under international law. ${ }^{11}$ If the looting was illegal, China and Chinese individuals can take legal action against the known possessors. Otherwise, claims for the return without a legal basis are usually silenced or, at best, discussed only but very rarely facilitated.

\section{Restitution of Cultural Relics Looted during WWII}

\section{A. The Hague Convention 1907 Prohibited the Looting of Cultural Relics}

The earliest legal instrument that China can rely on and use to claim for the return of its looted cultural relics from the Japanese Occupation is the 1899 Hague Convention on the Laws and Customs of War on Land. ${ }^{12}$ Japan ratified this Convention in 1900. Article 23 (g) of the Convention states that it is forbidden to destroy or seize the enemy's property, "unless such destruction or seizure be imperatively demanded

9 See War Damage on Cultural Relics Commission under the Department of Education 国民政府教育部 “清理战时 文物损失委员会, China Cultural Relics, Aug. 22, 2007, available at http://www.xhgxt.com/html/View_9270.html (last visited on Apr. 15, 2017).

10 See China Condemns Christie's Sculpture Sale, Warns of "Serious Effects," XINHUA News Feb. 26, 2009, available at http://news.xinhuanet.com/english/2009-02/26/content_10900960.htm (last visited on Apr. 15, 2017).

11 For details on the evolution of the law of war, see R. O'Keefe, The Protection of Cultural Property in Armed Conflict 30-2 (2006); L. Prott, The History and Development of Processes for the Recovery of Cultural Heritage, 1315 ART, ANTIQUITY \& L.175 (2008).

12 Convention (II) with respect to the Laws and Customs of War on Land (hereinafter 1899 Hague Convention). 
by the necessities of war." In other words, during hostilities monuments and buildings dedicated to art and science are ought not to be attacked or bombarded, unless it is necessary for military reasons. ${ }^{13}$ Accordingly, China could argue that Japan's notorious "Three Alls Campaign" was a clear violation of the 1899 Hague Convention, as it did not distinguish whether the specific situation was militarily necessary or simply destroying and looting all properties, including Chinese cultural heritages.

The 1899 Hague Convention also included two articles which were particularly designed to protect cultural heritage. Article 27 provides that in sieges and bombardments,

All necessary steps should be taken to spare as far as possible edifices devoted to religion, art, science, and charity, hospitals, and places where the sick and wounded are collected, provided they are not used at the same time for military purposes. ${ }^{14}$

The protection under Article 27 is preconditioned that the cultural heritage is used for 'military purposes,' rather than 'military necessity.' In the latter situation, it could still be destroyed if it "served to obstruct a line of attack, or ... to provide a shelter to which the enemy might retire, or in order to impede the enemy's advance, or the like" for the purpose of "military necessity. "15 According to Article 27, however, the use of cultural heritage for military purposes is not a breach of the Convention, which means the destruction of heritage can only be justified in the case of direct bombardment rather than in a broader sense of military necessity. ${ }^{16}$ Otherwise, had this phrase not been emphasized, damage to cultural heritage, whether by way of accident or direct targeting, would have been subject to military necessity and thus, should be allowed on a legal basis. By emphasizing the protection of cultural heritage, the Convention limits the lawfulness of attacks to very exceptional situations where a waiver can be invoked in case of 'military purposes.' Despite the precondition for 'military purposes, ${ }^{17}$ the destruction is not necessarily justified in all

13 O'Keefe, supra note 11, at 24.

14 Although the 1899 Convention was revised at the Second International Peace Conference in October 1907, only minor differences exist between the 1899 and the 1907 Convention. E.g., the 1899 Hague Convention did not include 'historic monuments' in the definition of cultural property. It was added to the definition by the 1907 Hague Conference. See C. Ehlert, Prosecuting the Destruction of Cultural Property in International Criminal Law 28 (2013).

15 O'Keefe, supra note 11, at 25-6.

16 C. Forrest, International Law and The Protection of Cultural Heritage 69 (2010). See also S. Nahlik, International Law and the Protection of Cultural Property in Armed Conflicts, 27 Hastings L. J. 1073 (1975).

17 While the term of 'military purposes' is not specifically defined, it was generally agreed that this included the use of buildings as offices and quarters for soldiers, or as signalling stations or observation posts to help target artillery. 
circumstances. If referring back to the general restriction embodied in Article 23(g), the destruction of enemy property is only justified when imperatively damaged by the necessity of war. ${ }^{18}$ Accordingly, China could argue that Japan's 1939 carpet bombing of Chongqing for two days of air raids was a clear violation of the Hague Convention on the ground that any bombardment directed at or likely to cause avoidable incidental injury to temples, art galleries, museums, historic monuments was prohibited. ${ }^{19}$

Article 56 of the Hague Convention 1899 also concerns cultural heritage in occupied territory. It states:

The property of the communes, that of religious, charitable, and educational institutions, and those of arts and science, even when State property, shall be treated as private property. All seizure of, destruction or wilful damage done to institutions of this character, historic monuments, works of art and science, is forbidden, and should be made the subject of legal proceedings.

In this regard, the obligation to protect both movable and immovable cultural property is absolute, without exception given for military purposes. ${ }^{20}$ Because cultural heritage may no longer constitute any threat to military operations under the control of an occupation force. Therefore, there is no need for a military necessity exemption to ensure a successful military outcome. ${ }^{21}$ Further, Article 56 stated that all cultural objects, including state property, should be treated as private property so that they could neither be confiscated (Article 46), nor pillaged (Article 47) by occupying forces. ${ }^{22}$ Thus, it can be concluded that the 1899 Hague Convention has placed an explicit prohibition of any seizure of cultural heritage as war booty. ${ }^{23}$ Accordingly, in a recent claim for the return of a 1300-year's old Tang dynasty stele,

See J. Edmonds \& L. Oppenheim, Land Warfare : An Exposition of the Laws and Usages of War on Land, for the Guidance of Officers of His Majesty's Army 136 (H. M. Stationery Office, 1912).

18 O'Keefe, supra note 11, at 24.

19 Id. at 25-6.

20 Nahlik, supra note 16, at 1074.

21 Forrest, supra note 16, at 69.

22 S. Ferrari \& A. Benzo, Between Cultural Diversity and Common Heritage: Legal and Religious Perspectives on the Sacred Places of the Mediterranean 304 (2014).

23 W. Downey, Captured Enemy Property: Booty of War and Seized Enemy Property, 44 Am. J. InT'L L. 497(1950). See also L. Woolsey, The Forced Transfer of Property in Enemy Occupied Territories, 37 AM. J. InT'L L. 285 (1943); L. Loucaides, The Protection of the Right to Property in Occupied Territories, 53 InT'L \& ComP. L. Q. 679 (2004); A. Bos, The Importance of the 1899, 1907 and 1999 Hague Conferences for the Legal Protection of Cultural Property in the Event of Armed Conflict, 57 Museum InT'L 36 (2005); C. Forrest, The Doctrine of Military Necessity and the Protection of Cultural Property During Armed Conflicts, 37 CALIF. W. InT'L L. J. 199 (2007). 
China should maintain a robust argument for the recovery. ${ }^{24}$ Considering that the Tang dynasty stele was founded in the early twentieth century and shipped by the Japanese military as a trophy of Japan's victory over the Russians in 1905 and the plundering of cultural property was already unlawful as per the 1899 Hague Convention, China should argue that the looting of Chinese cultural relics during the Japanese Occupation was illegal.

\section{B. Early Efforts for the Recovery of Chinese Cultural Relics}

Soon after the surrender of Japan in 1846, the "War Damage on Cultural Relics Commission" under the Department of Education was established to investigate the damage and loss of cultural relics during the Japanese Occupation and restore cultural relics and historical sites. ${ }^{25}$ In 1946, China's Department of Education requested: "Cultural relics taken by Japan since 1894 should be returned and all cultural relics discovered by Japan under the name of scientific research without the permission of the Chinese Government should be returned." ${ }^{26}$ As official requests sent to Japan, were to return these relics, some Chinese cultural relics were returned. On March 28, 1946, e.g., more than 25,000 ancient books which had been found in a library located in Ueno, Tokyo were returned. ${ }^{27}$

Regarding those Chinese cultural relics that were already in Japan, the Chinese Government requested the Allied Powers to pass special orders to protect Chinese relics and prevent them from being smuggled out of Japan. The request included imposing bans on any transfer or sale of Chinese cultural relics in Japan, stopping Japan taxing Chinese cultural relics held by private art dealers, requesting Japan to investigate and record all Chinese cultural relics taken by Japan since 1894, and imposing a total ban on any export of Chinese books published, before the Republic of China. ${ }^{28}$

\section{The 1972 Japan-Chian Joint Communiqué}

In general, though the recovery of Chinese cultural relics during the Japanese Occupation has proved challenging, primarily due to the Joint Communiqué. On

24 Perlez \& Feng, supra note 1.

25 Guidelines of the War Damage Commission 1945, art. 2.

26 Second Historical Archives of China, A Collective Documents about the People's(?) Republic of China 中华民国史档 案资料汇编第五册第三编, 5:3 Culture 449 (Jiangsu Phoenix House, 1999).

27 Id. at $449-50$.

28 Id. 
May 15, 1972, Japan and China issued a historic Joint Communiqué announcing their desire to normalize diplomatic relations, by which Japan recognized the People's Republic of China as the country's only legitimate government. ${ }^{29}$ An important issue contained in the 1972 Joint Communiqué refers to war-related reparations. Article 5 stated that China "declares that in the interest of the friendship between the Chinese and the Japanese peoples, it renounces its demand for war reparation from Japan."30

It is generally agreed that under the 1972 Joint Communiqué, the Chinese Government renounced its right for reparations. Then the question is whether individuals still have the means to vindicate their rights to request restitution even when the government had renounced its claims for war reparations against Japan in a peace treaty. Japan consistently argues that the 1951 Peace Treaty ${ }^{31}$ and the subsequent bilateral agreement have closed the door on the past and no individual claims may now be revamped. ${ }^{32}$ However, this point is not entirely clear or true, given that an increasing number of claims have been filed by private individuals against Japan's actions during the Second World War. Even though the individuals' rights were not extinguished by the 1972 Joint Communiqué, it is unclear whether the right to request restitution of looted cultural relics remains. Also, when individuals request restitution in a Japanese court the claim might be barred due to a statute of limitations. All these legal issues have made private claims difficult to be realized, that those deserve a critical analysis.

\section{Can Chinese Individuals Request Restitution of Looted Cultural Relics?}

\section{A. Rights of Individuals to Claim Compensation Are Not Excluded by Peace Treaties}

Japan consistently argues that the post-war treaty and agreements have resolved all war reparations. Such a defense has been successfully invoked by Japan in numerous

29 S. Smith, Intimate Rivals: Japanese Domestic Politics and A Rising China 108 (2015).

301972 Joint Communiqué art. 5.

31 The San Francisco Peace Treaty came into force on September 8, 1951, 3 U.S.T. 3169, available at https://treaties. un.org/doc/Publication/UNTS/Volume\%20136/volume-136-I-1832-English.pdf (last visited on Apr. 15, 2017).

32 It should be noted that this argument has succeeded in certain cases so far, e.g., Chinese civilian victims v. Japan. For details, see Hae-Bong Shin, Compensation for Victims of Wartime Atrocities: Recent Developments in Japan's Case Law, 3 J. InT'L Crim. Justice 190 (2005). 
cases to evade legal liability. In Deutsch v. Turner, ${ }^{33}$ e.g., the court simply rejected the claim by referring to the Article 14 of the 1951 Peace Treaty, which reads:

\begin{abstract}
Except as otherwise provided in the present Treaty, the Allied Powers waive all reparations claims of the Allied Powers, other claims of the Allied Powers and their nationals arising out of any actions taken by Japan and its nationals in the course of the prosecution of the war, and claims of the Allied Powers for direct military costs of occupation. $^{34}$
\end{abstract}

Nevertheless, questionable is whether it is correct to dismiss the case simply by referring to the peace treaty signed with Japan. The claims themselves remain correct. ${ }^{35}$ First, both Article 14 (b) of the Peace Treaty and Article 5 of 1972 Joint Communiqué speak of a waiver of 'reparations,' which is created on a governmentto-government basis, including intergovernmental payments for damage during the war, but no claims for private compensation. ${ }^{36}$ The UN Special Rapporteur, Gay McDougall, argues that the distinction in the text between 'reparations' and 'other claims' indicates that "the waiver does not apply to the compensation of Allied Powers' nationals" since "the only reparations contemplated in the waiver are those of the Allied nations themselves." ${ }^{37}$ Following this interpretation, only claims those qualify as something other than reparations claims, such as unpaid compensation and property claims, requested at the state level, would be barred. This opinion was shared in a Japanese case concerning Chinese victims of sexual violence. The judgment of the Tokyo District Court on April 24, 2003, distinguished between the terms 'war reparations' and "compensation for damages" in its ruling:

The Declaration is to be interpreted within the basic framework of international law; in this Declaration the counterpart, the People's Republic of China... only renounced the "war reparations" in relation to Japan, the offending State during the China-Japan War,

33 In Deutsch v. Turner (324. F.3d 692 (9th Cir 2003)), several individual and class actions lawsuits were filed in California by or on behalf of those prisoners against certain Japanese companies which benefited from sending thousands of prisoners of war to work under horrendous conditions in various Japanese industries. See S. MurPHY, United States Practice in International Law (vol.1: 1999-2001) 152-7 (2002).

341951 Peace Treaty art. 14(b).

35 Murphy, supra note 33 (vol. 2: 2002-04), at 315-6.

36 M. Bazyler, Holocaust Justice: The Battle for Restitution in America's Courts 316 (2005). See also R. Dolzer, The Settlement of War-Related Claims: Does International Law Recognize A Victim's Private Right of Action? Lessons after 1945, 20 BERKELEY J. INT'L L. 296-7 (2002).

37 G. McDougall, Contemporary Forms of Slavery: Systematic Rape, Sexual Slavery and Slavery-like Practice during Armed Conflict, U.N. Doc. E/CN.4/Sub.2/1998/13 (June 22, 1998), available at http://www1.umn.edu/humanrts/demo/ ContemporaryformsofSlavery_McDougall.pdf(last visited on Apr. 15, 2017). 
and did not renounce the so-called "compensation for damages", which are claims by individual victims belonging to the counterpart State. ${ }^{38}$

The court concluded that the 1972 Joint Communiqué does not necessarily contain the renouncement of individuals' claims for "compensation for damages." Also, another question is whether a subsequent treaty can trump a claim based on a violation of jus cogens norms under international law. ${ }^{39}$ Under international law, a jus cogens norm must not be departed or reversed by states in any circumstances. Hall and Oppenheim state: "A treaty becomes [void] ... by incompatibility with the general obligations of states, when a change has taken place in undisputed law or in views universally held with respect to morals." 40 Thus, if any provision of a treaty effectively conflicts the jus cogens rights or allows violations of jus cogens to go uncompensated, it is arguable that the provision would be void. Some scholars argued that the right to seek remedy for the violations of jus cogens norms is a jus cogens right in itself. ${ }^{41}$ On the other hand, while there is a near-universal agreement for the existence of the category of jus cogens norms, less agreement has been reached regarding the actual content of this category. ${ }^{42}$ According to the Vienna Convention on the Law of Treaties, jus cogens is "a norm accepted and recognized by the international community of States as a whole as a norm from which no derogation is permitted and which can be modified only by a subsequent norm of general international law having the same character." ${ }^{43}$ In other words, a jus cogens norm refers to certain fundamental and overriding principles that could reflect the general agreement and acceptance by States. Apparently, a feature common to jus cogens norms not only involves legal rules, but also reflects moral considerations and international good order. ${ }^{44}$ For Chinese individual requests for the restitution of cultural relics, the question remains as to whether the prohibition of looting cultural relics during armed conflicts amounts to a jus cogens norm.

To argue that the looting of cultural relics is a violation of a jus cogens norm, Chinese individuals could lay the foundation for their complaint by retracing the

38 Shin, supra note 32 , at 202.

39 S. Knuchel, State Immunity and the Promise of Jus Cogens, 9 Northwestern U. J. InT'L Hum. RTs. 153-4 (2011).

40 W. Hall \& A. Higgins, A Treatise on International Law 319 (1917). See also L. Oppenheim \& R. Roxburgh, International Law: A Treatise 528 (1920).

41 K. Parker \& J. Chew, Compensation for Japan's World War II War-rape Victims, 17 Hastings Int'L \& Comp. L. REV. 538-9 (1994)

42 I. Brownlie, Principles of Public International Law 517 (7th ed. 2008).

43 Vienna Convention on the Law of Treaties art. 53.

44 F. Schauer \& W. Sinnott-Armstrong, Philosophy of Law: Classic and Contemporary Readings with Commentary 604 (1995). See also Knuchel, supra note 39, at 153. 
recognition of the 1907 Hague Convention at the Nuremberg Tribunal. Although there is considerable debate as to when an international custom could be viewed as a new rule of customary international law, it is generally agreed that a certain level of agreement should be carried out on the issue that the customary rule regulates. ${ }^{45}$ At this point, the 1907 Hague Convention followed by the reparation provisions of both the Treaties of Versailles and Saint-Germain after the First World War not only prohibited the plunder, seizure or destruction of cultural relics such as monuments and art works, but also supported claims for restitution after the end of the war. ${ }^{46}$ Moreover, the 1954 Hague Convention and the two Protocols consolidated the rules of the 1907 Hague Convention pertaining to the protection of cultural relics. Basically, such principles as the prohibition of plundering cultural relics and ensuring obligation of restitution; the prohibition of acts using cultural relics as military targets except for military necessity; and the prohibition on retaining cultural relics as war reparations have been recognized by the international community. Also, these principles played an indispensable role in the protection and restitution of cultural relics during armed conflicts. ${ }^{47}$ Therefore, it could be argued that prohibiting the looting of cultural relics during armed conflicts amounts to a jus cogens norm.

Further, some Japanese courts are unwilling to accept that individual claims to compensation can be extinguished by post-war settlement treaties. ${ }^{48}$ The judgement of the Fukuoka District Court on April 26, 2002, should be mentioned here as an important example against the argument that the 1972 Joint Communiqué renounced Chinese individuals' rights to claim war reparations. ${ }^{49}$ The court admitted that the meaning of the Japan-China Joint Communiqué was ambiguous on the renunciation of individuals' rights to the compensation and that "important materials in filing this suit such as the reports of the Ministry of Foreign Affairs and their foundational

45 There is a considerable debate surrounding the four elements of state practice as follows: duration, uniformity, consistency and generality. This paper does not aim to resolve this debate. For details on CIL, see M. SHAw, International Law 51-66 (2014); M. Akehurst, Custom as a Source of International Law, 47 Brit. Y.B. INT'L L. 1-53 (1975); A. D’Amato, The Concept of Custom in International Law (1971); K. Wolfke, Custom in Present INTERNATIONAL LAW (1993).

46 J. Nafziger \& R. Paterson, Cultural Heritage Law, in Handbook on the Law of Cultural Heritage and International Trade 4 (J. Nafziger \& R. Paterson eds., 2014).

47 F. Francioni \& J. Gordley, Enforcing International Cultural Heritage Law 164 (2013). See also W. Sandholtz, Prohibiting Plunder: How Norms Change 256-7 (2007).

48 Shin, supra note 32 , at 201-3.

49 Chinese victims of forced labour v. Japan and Mitsui Mining Inc., Fukuoka District Court, Apr. 26, 2002. See id. at 199. 
materials had been concealed by the intervention of the defendants. ${ }^{, 50}$ The judgment of the Niigata District Court of March 26, 2004, also took the same position. The court held that it was difficult to maintain the right to claim compensation for damage suffered by individual Chinese citizens, especially those based on the violation of the obligation of security which was renounced by the Japan-China Joint Communiqué. ${ }^{51}$

Therefore, it can be argued that it is wrong to dismiss individuals' claims simply by referring to the peace treaty. Japan cannot rely on the 1972 Joint Communique to absolve its liability to solve individuals' claims for unlawful acts during World War II.

\section{B. Right to Individual Compensation under International and Japanese Law}

If Chinese individuals' claims are not waived by the treaty, the next question is whether private individuals have the standing as direct beneficiaries of war damages. As individuals are not usually considered capable of bringing international claims against States, it is unclear whether they can invoke the treaty rights of the State parties which are founded on the general principle of State responsibility. ${ }^{52}$

At this point, Japanese courts were extremely reluctant to accept the argument that an individual victim has the right to obtain compensation for damages. In cases involving 'comfort women,' e.g., the Japanese courts simply rejected the claims for the reason that individuals do not have the capacity to demand compensation for violations of international humanitarian law, without even finding that Japan's actions constituted violations of international law. ${ }^{53}$

Nevertheless, throughout history, the standing of individual victims as direct beneficiaries of state compensation for war damages has existed since early twentieth century. When the International Prize Court was established in 1907, it allowed individual victims to claim property rights for damage as a result of State acts. ${ }^{54}$ In addition, in 1907, the Central American Court of Justice allowed not only States, but also individuals and domestic institutions to bring claims against a State for the

50 Id.

51 Chinese victims of forced labour v. Japan and Rinko Corporation, Niigata District Court, Mar. 26, 2004. See id. at 202.

52 W. Dunlap, R. Pritchard \& J. Carey, International Humanitarian Law: Prospects 247-8 (2006).

53 See, e.g., Former POWs and civilian detainees of the ex-allied powers v. Japan, Tokyo District Court, Nov. 26 1998; Philippine ‘comfort women' v. Japan, Tokyo District Court, Oct. 9, 1998.

54 C. Chinkin \& G. Aldrich, A Century of Achievement and Unfinished Work, 94 Aм. J. INT’L L. 98 (2000). 
violation of treaties or other cases under public international law. ${ }^{55}$ However, the standing of individual victims has been, in general, rather weak. Among the five individual claims, the Central American Court of Justice ruled between 1908 and 1918 , e.g., four cases were dismissed because of "non-exhaustion of local remedies" and the last one was ruled against the individual. ${ }^{56}$ Despite the weak standing, the possibility of individual victims to bring about a claim for compensation under public international law, should not be excluded. The Treaty of Versailles of 1919 provided that individual nationals of the Allied and Associated Powers could bring cases against Germany through a Mixed Arbitral Tribunal, the decisions of which would be "final, conclusive and binding upon their nationals." treaties were established following the First World War that granted individuals access to redress mechanisms and, in some cases, even recognized the right of individuals to turn to arbitral tribunals to claim compensation from a State. ${ }^{58}$

Moreover, the articulation of the principle on compensation has been widely endorsed in both international and the domestic court decisions. In Chorzow Factory, the Permanent Court of International Justice ("PCIJ") reaffirmed that States should pay individual compensation. ${ }^{59}$ In this ruling, the PCIJ held: "Any breach of an engagement invokes an obligation to make reparation" and that "reparation must, as far as possible, wipe out all consequences of the illegal act and re-establish the situation which would ... have existed if the act had not been committed." similar decision was made by a Japanese court in a case concerning Chinese victims of sexual violence during Japanese Occupation. ${ }^{61}$ In the case of Chinese victims of sexual violence v. Japan, the court asserted:

55 I. Bottigliero, Redress for Victims of Crimes under International Law 83 (2004).

56 Id.

57 Treaty of Versailles 1919 art. 304(b).

58 E.g., the Arbitral Tribunal was established between Germany and Poland under the Convention for the Protection of Minorities of 15 May 1922. It allowed individual claims against the state of nationality and the foreign state on various issues, including nationality, right of residence, etc. See Bottigliero, supra note 55, at 84.

59 Chorzow Factory Case, Judgment 1928 P.C.I.J. (ser. A), No. 17, at 47-48 (Sept. 13). These endorsements include leading judgements on damage for injuries to the UN personnel and reparations for human rights violations. Also, there were international attempts directed at codifying the elements of compensation in connection with State responsibility under international law such as the Harvard Draft of the Law of Responsibility of States for Damages Done in their Territory to the Persons or Property of Foreigners. See Looking Ahead: International Law in the 21st Century: Proceedings of the 29th Annual Conference of the Canadian Council on International Law, Ottawa, Oct. 26-28, 2000 (2002), at 252; Reparation for Injuries Suffered in the Service of the United Nations, Advisory Opinion, 1949 I.C.J. Rep. (Apr. 11), available at http://www.icj-cij.org/docket/files/4/1837.pdf (last visited on Apr. 15, 2017).

60 Parker \& Chew, supra note 41, at 524. See also McDougall, supra note 37, at 4.

61 Y. Takahashi, The Law of Occupation: Continutty and Change of International Humanitarian Law, and Its Interaction with InTERnational Human Rights LaW 381 (2009). 
It is the proper right of the injured citizen to claim compensation for damages from the offender, and even if the offender is a State to which the citizen does not belong, the renunciation of the victims claims for compensation by means of a treaty concluded between the State to which the citizen belongs and another State should be limited to cases where alternative measures are taken, such as when the former State itself performs the obligation to make compensation to the victims who are its nationals. ${ }^{62}$

More importantly, it is worth noting that Japanese courts are tending towards supporting individuals' claims for compensation for unlawful acts during World War II within its domestic legal regime. ${ }^{63}$ Before Japan's State Compensation Law of 1947 explicitly stipulated that States should pay compensation for damage caused by illegal acts of public officials while performing their duties, the pre-war legal system in Japan had not maintained a clear framework for compensation in such cases. Despite the absence of specific regulations, individual claims brought against unlawful acts made by Japan during World War II had been admitted to Japanese courts pursuant to the Japanese civil law. ${ }^{64}$ Further, on April 27, 1998, a Japanese court ordered the Japanese Government to pay compensation to three Korean 'comfort women', the plaintiffs, who were victims of sexual slavery by the Japanese Imperial Forces from 1931 to $1945 .{ }^{65}$ The court admitted that the 'comfort woman' system not only violated international law, but also employed Japan's domestic tort law to carry out their constitutional duty to enact an appropriate compensation law. ${ }^{66}$ The court summarized that the 'comfort woman' system "was a manifestation of sexism and racism of the time which severely violated the dignity of women and profoundly damaged racial pride; and that it is not the past issue but the ongoing

62 Chinese victims of sexual violence v. Japan, Tokyo District Court, Apr. 24, 2003. See Shin, supra note 32, at 202.

63 In Chinese victims of Nanking Massacre and inhuman acts by the Unit 731 of the Japanese army v. Japan, on September 22, 1999, the Tokyo District Court confirmed that the 'Nanking Massacre' and the alleged atrocities committed by Unit 731 were undisputed facts and recognised that the plaintiffs had been subjected to cruel and inhuman treatment as claimed. However, before examining the plaintiffs' claim for compensation, the Court was conspicuous for its peculiar assumption regarding compensation for individuals as follows:

To admit the rights of individuals to claim, from foreign States, compensation for damages suffered during a past war without relying upon diplomatic negotiations between States is ... equivalent to leaving seeds of conflict, and harmful in view of preventing future wars... This Court considers it appropriate not to recognize something which could be an excuse for another war as a right under international law, even though it may run counter to justice at the level of general civil law.

See id. at 191-4.

64 Id. at 191.

65 E. Totsuka, Commentary on a Victory for "Comfort Women": Japan's Judicial Recognition of Military Sexual Slavery, 8 PAC. Rim L. \& PoL'y J. 47-8 (1999).

66 Id. at 48 . 
human rights issue that should be resolved now." ${ }^{\circ 7}$ The court went a step further, holding that the Japanese Government was negligent in its legislative activities:

It is the legislature's failure, after the passing of a certain reasonable period, to enact reparatory legislation in cases where grave human-rights violations occurred and the imperative necessity to take remedial action was at stake, was unlawful under the State Compensation Law, especially under the present Constitution, which enshrines fundamental values of respect for individuals and human dignity. ${ }^{68}$

This case is of a great significance for post-war compensation. First, although the Japanese Government insisted on denying liability, the court found the testimony of the Korean 'comfort women' and forced laborers to be sufficiently credible to establish the facts, to which it applied Japanese legal standards. These court-found facts will be an important tool to force Japan to come to terms with its wartime aggression. Second, it is the first time that a Japanese court ruled in favour of foreign plaintiffs in a post-war compensation case. This ruling is a clear example of the exception to the principle of legislative immunity. The judgement could serve as a starting point for the acceptance of the argument that Japan cannot simply waive its legal responsibly upon the doctrine of the irresponsibility of the State. [Emphasis added]

In the case concerning the forced transportation and forced labour of Chinese people, further, the judgement of the Kyoto District Court on January 15, 2003, found the acts of the government to be unlawful and refused to admit the doctrine of the irresponsibility of the State. ${ }^{69}$ The court held:

Even if we can affirm, in general, that authoritative acts of State to which the doctrine of the irresponsibility of the State applies once existed; the forceful acts inflicted on the six plaintiffs were nothing less than unlawful acts, as this Court mentioned, and were not authoritative acts subject to protection. The submission of the Defendant State is baseless because its underlying argument is faulty. ${ }^{70}$

In a similar case brought to the Tokyo District Court, though the claims were rejected due to the statute of limitations, the court agreed that the application of the doctrine of the irresponsibility of the State to the case at issue was "illegitimate

$67 \quad I d$.

68 Shin, supra note 32, at 194.

69 Chinese victims of forced labour v. Japan and the company A (undisclosed), Kyoto District Court, Jan. 15, 2003.

70 Shin, supra note 32, at 195. 
and unreasonable."71 The judgement of the Niigata District Court of March 26, 2004, concerning forced transportation and forced labour during World War II, also provides the most significant decision so far. ${ }^{72}$ It is the first time that the court has recognized the responsibility of the government and ordered it to pay compensation. The court stated: "It is hard to find, under present laws which abolished administrative tribunals and made all litigation both in areas of public and private law to be heard by ordinary courts, any reasonableness or legitimacy in the idea itself of denying claims for damage against the State." ${ }^{, 73}$ Therefore, it can be argued that there is a growing tendency for Japanese courts to support individual claims for the compensation of unlawful acts during World War II.

\section{Statute of Limitations}

A statute of limitations is another legal hurdle for all post-war compensation claims. According to Japans' Specified Foreign Cultural Property, victims of theft are required to claim for the recovery of property from the possessor within a total period of ten years of the theft. ${ }^{74}$ Also, the concept of Ausschulussfrist which does not allow interruption and has the effect of extinguishing rights with the absence of the exercise of such rights by those concerned, has been widely recognized in both theories and judgements in civil law countries, including Japan. ${ }^{75}$ Thus, if Ausschulussfrist was admitted in post-war compensation claims, the chances of the Chinese individuals winning the restitution would be very small. Chinese individuals would be time-barred from bringing their claims in a Japanese court, given that over seventy years have passed since the alleged acts.

71 The court stated: "It is hard to find reasons for this Court, in interpreting the provision on unlawful acts in civil law under the system that prevailed before the State Compensation Law took effect, to be bound by the above doctrine, an unwritten legal principle that does not have any statutory basis, to the same extent as by positive law." See Chinese victims of forced labour v. Japan and Hazamagumi Inc. et al., Tokyo District Court, Mar. 11, 2003 (unpublished), at 25-6. See also id. at 196.

72 The defendants immediately appealed, but the latest documents have not been found.

73 Chinese victims of forced labour v. Japan and Pinko Corporation, Niigata District Court, Mar. 26, 2004, at 88. The defendants immediately appealed, but the latest documents have not been found.

74 As Japan's Civil Code allows a victim to claim stolen or lost property from a bona fide purchaser, such a claim should be made within two years from the time of the loss or theft. This short period makes Japan a 'safe harbour' for illegally transferred cultural relics. Following criticism from abroad, Japan has enacted the Specified Foreign Cultural Property. See Shigeru Kozai \& Toshiyuki Kono, Japan, in Nafziger \& Paterson, supra note 46, at 267.

75 The concept of Ausschulussfrist has been particularly recognised in the interpretation of the latter part of Article 724 of the Civil Code which reads: "The right to demand compensation for damages in tort shall be extinguished by the operation of prescription if it is not exercised by the victim or his/her legal representative within three years from the time when he/she comes to know of the damages and the identity of the perpetrator. The same shall apply when twenty years have elapsed from the time of the tortious act." See Shin, supra note 32, at 197. 
However, some recent judgements have shown that Japanese courts are unwilling to admit Ausschulussfrist in the post-war compensation claims, classifying the process as being contrary to justice and fairness. In the case concerning forced labour during the Japanese Occupation, the Tokyo District Court on July 12, 2001, admitted Ausschulussfrist in line with the jurisprudence of the Supreme Court, thereby absolving the government's responsibility. However, it argued the application to this case would be contrary to ideals of justice and fairness. The court asserted that "to give immunity to such defendant by applying the system of Ausschulussfrist ... is, considering the seriousness of damage the victim suffered, extremely contrary to justice and fairness." ${ }^{, 76}$ In the other case concerning forced transportation and forced labour, the Fukuoka District Court on April 26, 2002, ultimately resolved the barrier of time for the first time, refusing applications of a statute of limitations to the case. The court alleged: "It is extremely contrary to the ideal of justice and equity to give immunity to the responsibility ... and it is appropriate to restrict the application [of the latter part of Article 724 of the Civil Code].” On May 24, 2004, however, the Fukuoka High Court overruled this decision. While the High Court admitted the responsibility of the government and the company for their unlawful acts and denied compensation by applying Ausschulussfrist. Thus, it could be concluded that considerable development on interpretation in favour of individuals' claims can be found in recent judgements, while the issue of the statute of limitations still remains the toughest legal obstacle in all post-war compensation claims.

Moreover, it should be noted that the policy rationale behind imposing a time bar is "diligent prosecution of known claims, thereby providing finality and predictability in legal affairs and ensuring the claims will be resolved while evidence is reasonably available and fresh." ${ }^{, 77}$ When plaintiffs do not unduly delay bringing suits and the evidence is still very compelling, individuals' claims for compensation for unlawful acts during World War II, which should not be barred simply on the grounds of time limitations. Also, it would be unfair to allow Japan to claim a time bar when Japan itself has been in custody for most of the documentary evidence. ${ }^{78}$ In this respect, Germany enacted post-war legislation suspending the statute of limitations for prosecuting previously undetected egregious offenses during World War II until the year 2009. Similarly, in 2002, the California legislature amended California Code of Civil Procedure $\S 338$ (c) to extend the statute of limitations from

76 Id. at 198.

77 M. Arakawa, A New Forum for Comfort Women: Fighting Japan in United States Federal Court, 16 BerkeLEY Women's L. J. 191 (2001).

78 Parker \& Chew, supra note 41 , at 540. 
three to six years, allowing victims of the Holocaust to seek the return of their looted cultural treasures from a museum, gallery, auctioneer or dealer. ${ }^{79}$ The law was made explicitly retroactive and the statute of limitations did not commence until actual discovery of both the identity and location of the work. Thus, strong arguments exist for legal or equitable tolling of the statute of limitations in the post-war claims against Japan.

\section{Conclusion}

Although countless Chinese cultural relics were destroyed or looted during the Japanese Occupation, no Chinese individual has brought a case before a court for the restitution of these relics. Despite the silence in private claims and frustration with Japan's continued efforts to revise the views of its history of military aggression, there is a strong indication that the Chinese Government should seek the redress of unlawful Japanese acts during wartime. ${ }^{80}$ Since July 2014, China has begun publicizing the confessions of Japanese war criminals who were tried by Chinese tribunals in the early 1950s. This can be critical evidence before the court. ${ }^{81}$

Due to the 1972 Joint Communiqué, whether Chinese individuals have the standing to request restitution against Japan is of great importance. In this case, individuals have a legal basis to request restitution under public international law. The restitution of looted cultural relics based on individual rights is legally complex, as it mixes private with public international law. Despite the legal hurdles, Chinese individual rights still have a case to seek the restitution of looted cultural relics from Japan.

79 B. Acquaviva, The Latest in Nazi-Era Restitution Efforts, Center for Art Law, Mar. 24 2016, available at https:// itsartlaw.com/2016/03/24/the-latest-in-nazi-era-restitution-efforts (last visited on Apr. 15, 2017).

80 Hidenori Ijiri, Sino-Japanese Controversy since the the 1972 Diplomatic Normalization, 124 CHINA Q. 639 (1990).

81 A. Ramzy, Xi Condemns Efforts to Play Down Japan's Wartime Aggression, N.Y. Times, July 7, 2014, available at http://sinosphere.blogs.nytimes.com/2014/07/07/xi-condemns-efforts-to-play-down-japans-wartime-aggression (last visited on Apr. 15, 2017). 